\title{
ANALISIS KESALAHAN SISWA DALAM MENGERJAKAN SOAL PENJUMLAHAN DAN PENGURANGAN PECAHAN BERDASARKAN KRITERIA WATSON
}

\author{
Dedi Pramada $^{1}$, Hajerina ${ }^{2}$ \\ ${ }^{1}$ Program Studi Pendidikan Matematika, FKIP, Universitas Alkhairaat \\ Dedi_pramada@gmail.com \\ 2,3Program Studi Pendidikan Matematika, FKIP, Universitas Muria Kudus \\ Hajrinahamid@gmail.com
}

\begin{abstract}
ABSTRAK
Penelitian ini bertujuan untuk mengetahui kriteria kesalahan yang dilakukan oleh siswa di SDN 7 Sindue dalam menyelesaikan soal cerita pada operasi pecahan berdasarkan teori Watson. Subjek penelitian terdiri dari 3 orang siswa yang masing-masing berkemampuan tinggi, sedang, dan rendah dilihat dari peringkat yang diperoleh. Berdasarkan hasil penelitian yang dilakukan kriteria kesalahan yang banyak dilakukan oleh siswa berdasarkan teori watson adalah kesalahan tipe Id (data tidak tepat), Ip (Prosedur tidak tepat), Od (Data yang hilang), Oc (kesimpulan yang hilang), Rlc (Konflik level respon), Um (Manipulasi tidak langsung), Shp (Hirarki keterampilan). Dan kesalahan yang paling banyak dilakukan oleh subjek 1, 2, dan 3 adalah kesalahan tipe IP (Prosedur Tidak Tepat), dan RLC (Konflik Level Respon).
\end{abstract}

Kata Kunci : Operasi Pecahan, Kriteria Kesalahan, Teori Watson

\begin{abstract}
This study aims to determine the criteria for errors made by students at SDN 7 Sindue in solving story problems on fraction operations based on Watson's theory. The research subjects consisted of 3 students, each of whom had high, medium, and low abilities according to the ranking obtained. Based on the results of research conducted, the criteria for errors that are mostly carried out by students based on Watson's theory are error type Id (incorrect data), Ip (incorrect procedure), Od (missing data), Oc (missing conclusion), Rlc (level conflict response), Um (Indirect manipulation), Shp (Skills hierarchy). And the most common mistakes made by subjects 1, 2, and 3 are IP (Inappropriate Procedure), and RLC (Response Level Conflict) errors.
\end{abstract}

Keywords: Fraction Operations, Error Criteria, Watson's Theory

\section{PENDAHULUAN}

Matematika yang telah diajarkan sangatlah penting juga untuk mengevaluasi apa saja yang sudah dapat dicapai dan apa saja yang menjadi kendala dalam mempelajari atau menyelesaikan persoalan matematika. Hasil evaluasi belajar siswa merupakan salah satu cara untuk dapat mengetahui sejauh mana perkembangan siswa dan tercapainya tujuan belajar terutama dalam pelajaran matematika yang masih dirasa sulit bagi siswa dibandingkan materi lainnya. Sehingga perlu dilakukan penelit ian untuk menindak lanjuti evaluasi hasil belajar siswa dengan menganalisis hasil belajar siswa agar dapat diketahui kesulitan yang di alami oleh siswa dan pendidik.

Penyelesaian masalah matematika, dimana tugas guru adalah membantu siswa dalam menyelesaikan masalah dengan spektrum yang luas yakni membantu siswa dalam memahami masalah, sehingga kemampuan dalam memahami 
konteks masalah bisa terus berkembang menggunakan kemampuan inquiri dalam menganalisa alasan mengapa masalah itu muncul.

Pada umumnya permasalahan yang dihadapi oleh siswa di matematika berupa pemecahan masalah yang didalamnya termuat soal cerita. Untuk meengembangkan kemampuan siswa dalam pemecahan masalah hal yang perlu ditingkatkan adalah kemampuan menyangkut beberapa hal teknik dan strategi pemecahan masalah, pengetahuan, keterampilan, dan pemahaman merupakan elemen-elemen penting dalam belajar matematika. Sehingga siswa dapat mencapai tujuan pembelajaran matematika terutama dalam hal menyelesaikan soal cerita yang dianggap memiliki tingkat kesulitan yang lebih.

Soal cerita mempunyai beberarapa kelebihan selain biasanya soal cerita menceritakan kasus keseharian yang ada dilingkungan sekitarnya, soal cerita juga membutuhkan pemahaman bahasa yang baik sehingga dapat mengubahnya ke dalam bentuk operasi matematika, bisa juga melihat bagaimana cara berfikir siswa dalam mengerjakannya, dibandingkan dengan siswa langsung dibberiikan dalam bentuk operasi matematika.

Keterampilan menyelesaikan soal cerita juga memegang peran penting dalam jangka panjang karena aplikasi matematika dibidang lain selalu berkaitan dengan pembuatan model matematika. Seperti yang dikatakan oleh Daavis dan Mc Killip (Budiono: 2008) "Walaupun keterampilan menyelesaikan soal cerita memmegang peran penting dalam jangka panjang, tetapi soal cerita bukan hal yang mudah bagi siswa untuk mengerjakannya dan juga bukan hal mudah bagi guru untuk mengajarkannya."

"Soal cerita biasanya diwujudkan dalam kalimat yang yang di dalamnya tersembunyi persoalan atau permasalahan yang penyelesainnnya menggunakan keterampilan menghitung. Dengan demikian dilihat bentuknya, soal cerita biasanya berbentuk tes uaraian. Jika dikaitkan dengan taksonomi Bloom, soal cerita yang berbentuk uraian tersebut berada pada ranah ap likasi. Pada tahapantahapan tertentu, soal cerita yang berbentuk uraian dapat dikategorikan kedalam ranah sintesis dan analisis."

Berdasarkan tujuan yang ada, soal cerita dapat digunakan untuk untuk melihat nalar siswa. Untuk dapat mengerjakan soal cerita dengan baik, para siswa harus dapat menangkap apa yang dipermasalahkan dalam soal tersebut. Tentu saja ini merupakan kegiatan kognitif tingkat tinggi. Setelah mengetahui apa yang dipermasalahkan, para siswa dituntut untuk dapat membuat model matematikanya. "Model matematika diwujudkan dalam kalimat matematika (biasanya operasi hitung). Dengan menyelesaikan kalimat matematika tersebut, persoalan yang ditanyakan dapat dijawab."

Salah satu teori yang digunakan dalam penelitian untuk menganaisis kesalahan siswa dalam mengerjakan soal cerita ialah Teori Watson. Diantanya Kurnia Ayu Winarsih dkk dengan judul "Analisis Kesalahan Siswa Berdasarkan Kategori Menurut Watson dalam Menyelesaikan Permasalahan Pengolaan Data Siswa Kelas VI SDN Baletbaru 02 Sukowono Jember Tahun Pelajaran 2014/2015”, Aris Arya Wijaya dan Masriya dengan judul "Analisis Kesalahan Siswa dalam Menyelesaikan Soal Cerita Materi Sistem Persamaan Linier Dua Variabel" dan juga beberapa pelitian lainnya.

Materi operasi hitung pada pecahan merupakan materi yang harus dikuasai oleh siswa sejak dari Sekolah Dasar. Hal ini disebabkan materi operasi hitung pada pecahan ini adalah materi dasar atau materi pelajaran yang menjadi prasyarat untuk dapat menguasai materi-materi selanjutnya yang akan dijumpai siswa pada jenjang pendidikan yang lebih tinggi. Misalnya pada jenjang SMP, operasi pecahan akan digunakan pada materi luas dan volume bangun ruang dan di jenjang SMA akan digunakan pada materi logaritma dan trigonometri.

Berdasarkan hal tersebut, penting bagi siswa dan guru untuk 
meminimalisasikan kesalahan kesalahan yang akan dilakukan oleh siswa dalam menyelesaikan soal-soal terkait materi operasi hitung pecahan. Tindakan meminimalisasikan kesalahan tersebut dilakukan peneliti dengan melakukan penelitian mengenai analisis kesalahan yang di klasifikasikan berdasarkan kriteria kesalahan Watson.

Penggunaan kriteria kesalahan Watson ini, secara umum cocok digunakan untuk menganalisis kesalahan hasil pekerjaan siswa. Hal ini didukung oleh kriteria kesalahan Watson yang mengukur letak kemampuan kognitif siswa dalam mengerjakan soal-soal tes. Kriteria kesalahan menurut Watson terdiri dari delapan kesalahan, yaitu data tidak tepat, prosedur tidak tepat, data hilang, kesimpulan hilang, konflik level respon, manipulasi tidak langsung, masalah hierarki keterampilan dan selain ketujuh di atas (Moh. Asikin: 2003).

Dari adanya kesalahan-kesalahan yang dilakukan siswa dalam mengoperasikan bilangan pecahan dan berdasar pada hasil wawancara mengenai permasalahan yang dihadapi oleh siswa dalam mengerjakan soal cerita. Maka perlu adanya identifikasi kesalahan siswa dalam pengerjaan soal cerita matematika, yang akan dikaji dalam sebuah judul yaitu "Analisis Kesalahan Siswa dalam Mengerjakan Soal Penjumlahan dan Pengurangan Pecahan Berdasarkan Kriteria Watson". Peneliti menggunakan kriteria watson.

\section{METODE PENELITIAN}

Penelitian ini merupakan penelitian kuantitatif deskriptif. "Dalam penelitian ini, hal yang awal dilakukan adalah menentukan latar belakang masalah dan rumusan masalah, setelah itu masalah di identifikasi. Selanjutnya peneliti mencari sumber-sumber teori yang mendukung dalam penelitian untuk menguatkan penelitian yang diinginkan. Setelah itu peneliti menentukan subjek untuk penelitian. Subjek penelitian adalah 3 siswa kelas V SDN 7 Sindue Tahun ajaran 2018/2019 sebagai informan yang akan dianalisis hasil penyelesaian soal penjumlahan dan pengurangan pecahan. Siswa yang dijadikan subjek dipilih berdasarkan klasifikasi peringkat yang diperoleh

Teknik pengumpulan data yang dilakukan yaitu melalui tes dan wawancara. Peneliti membuat instrumen yang sesuai dengan tujuan penelitian dengan mengumpulkan soal-soal yang berkaitan dengan materi yang digunakan dalam peneletian. Soal-soal tersebut dipilih dan dijadikan tes. Pemilihan soal berdasarkan materi-materi yang biasa muncul dalam soal ujian nasional dan berbentuk soal cerita. Wawancara digunakan untuk menggali informasi dan pendapat siswa sehingga memperoleh gambaran yang lebih komprehensif tentang informasi yang diinginkan. Data wawancara dikumpulkan melalui rekaman suara. Selanjutnya, data tersebut akan diubah ke dalam bentuk teks.

Instrumen penelitian yang dipakai dalam penelitian ini adalah tes tulis. Siswa diberikan soal sebanyak 1 soal cerita yang dikerjakan dalam waktu 20 menit. Siswa mengerjakan dalam bentuk uraian. Soal tersebut dipilih sesuai dengan kriteria Watson dalam pengajarannya seperti ada manipulasi rumus, ada kesimpulan akhir dan lainnya. Penelitian ini menggunakan analisis kualititatif deskriptif. Analisis deskriptif adalah menganalisis data dengan cara mendeskripsikan atau menggambarkan data yang telah terkumpul sebagaimana adanya tanpa bermaksud membuat kesimpulan yang berlaku umum atau generalisasi

\section{HASIL DAN PEMBAHASAN}

\section{A. Hasil Penelitian}

Penelitian ini dilakukan saat setelah ujian kenaikan kelas, dimana siswa telah mendapatkan semua materi sehingga tidak ada alasan bagi siswa bahwa soal test yang diberikan belum diajarkan oleh guru. Soal tes yang diberikan sudah sesuai dengan materi yang telah ditetapkan Dinas Pendidikan. Tes pun dilakukan tanpa pemberitahuan kepada siswa. Siswa yang dijadikan subjek penelitian hanya berjumlah 3 orang diambil berdasarkan peringkat yang diperoleh siswa. Siswa 
pertama dipilih dari rentan peringkat 1 10 , siswa kedua dari peringkat $11-20$, dan siswa ketiga dari peringkat $21-30$. Setelah diberikan tes kepada siswa, selanjutnya peneliti mengkaji jawaban para siswa. Dari jawaban para siswa, peneliti dapat mengetahui kesalahan-kesalahan yang dilakukan siswa dalam menyelesaikan soal cerita pada materi penjumlahan dan pengurangan pecahan. Berikut ini deskripsi kesalahan pada jawaban siswa.

\section{Subjek Pertama}

Tabel 1. Deskripsi kesalahan dari jawaban subjek pertama

\begin{tabular}{|l|l|}
\hline \multicolumn{1}{|c|}{ Deskripsi Kesalahan Siswa } & Ada / Tidak Ada \\
\hline Data tidak tepat & - \\
\hline Prosedur tidak tepat & Ada \\
\hline Data yang hilang & - \\
\hline Kesimpulan Hilang & - \\
\hline Konflik level respon & - \\
\hline Manipulasi tidak langsung & - \\
\hline Hirarki keterampilan & - \\
\hline Tidak mengerjakan & - \\
\hline
\end{tabular}

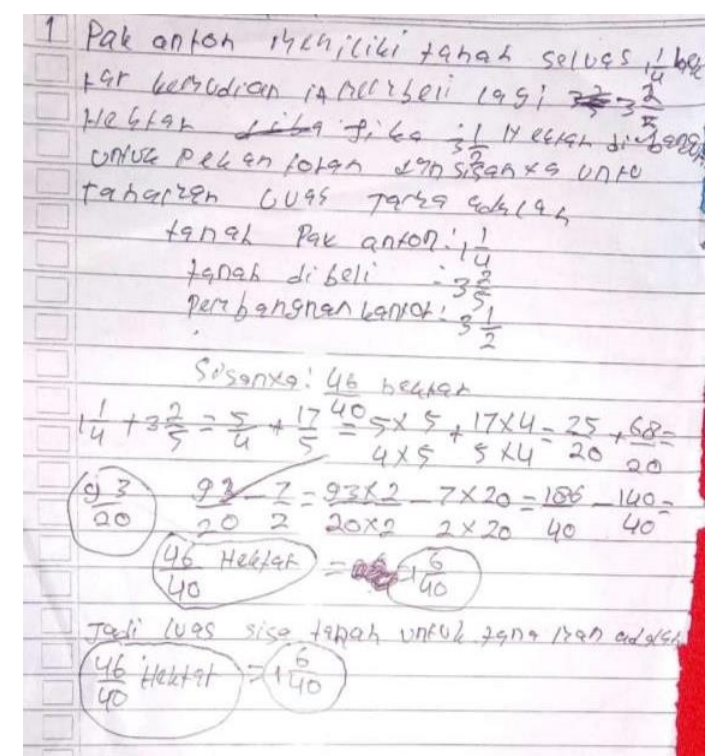

Gambar 1. Jawaban subjek pertama

Dari jawaban subjek pertama diatas dan berdasarkan pada tabel 1 tentang deskripsi kesalahan yang dilakukan oleh subjek, kesalahan yang dilakukan yang dilakukan subjek pertama ialah prosedur yang tidak tepat. Pada proses pengerjaan soal yang dilakukan oleh subjek pertama memiliki kekeliruan pada saat melakukan penyamaan penyebut yakni subjek pertama tidak menuliskan garis "per" pada $\frac{5 \times 5}{4 \times 5}, \frac{7 \times 20}{2 \times 20}, \frac{140}{40}$. Namun langkah pengerjaan soal yang dilakukan subjek pertama sudah cukup baik.

\section{Subjek Kedua}


Tabel 2. Deskripsi kesalahan dari jawaban subjek kedua

\begin{tabular}{|l|l|}
\hline \multicolumn{1}{|c|}{ Deskripsi Kesalahan Siswa } & Ada / Tidak Ada \\
\hline Data tidak tepat & Ada \\
\hline Prosedur tidak tepat & Ada \\
\hline Data yang hilang & - \\
\hline Kesimpulan Hilang & - \\
\hline Konflik level respon & Ada \\
\hline Manipulasi tidak langsung & - \\
\hline Hirarki keterampilan & Ada \\
\hline Tidak mengerjakan & - \\
\hline
\end{tabular}

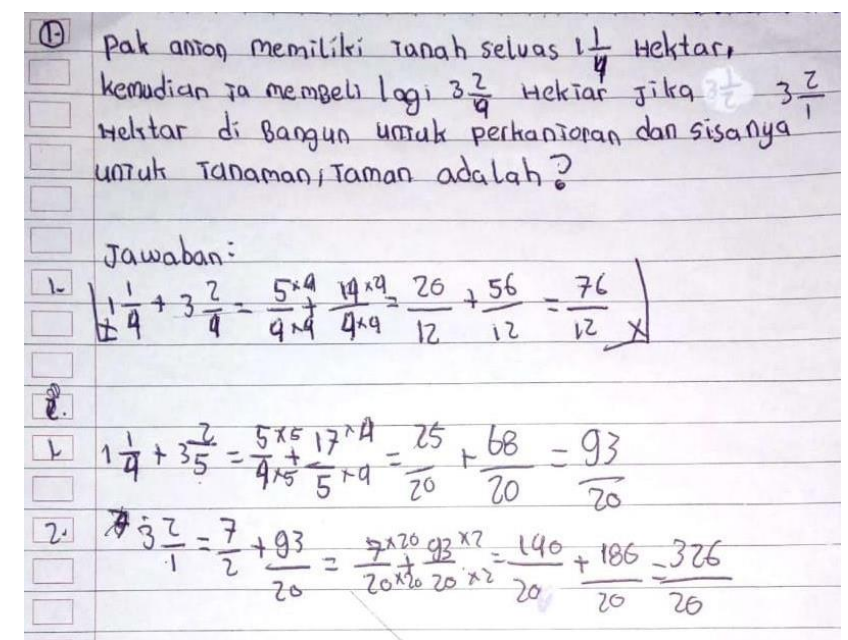

Gambar 2. Jawaban subjek kedua

Untuk subjek kedua, memiliki kesalahan pada penggunaan prosedur yang tidak tepat dan hirarki keterampilan. Pada kasus prosedur yang tidak tepat kesalahan yang dilakukan oleh subjek ialah pada pengerjan soal tahap kedua yang semestinya jumlah keseluruhan tanah dari Pak Anton dikurangi dengan luas tanah yang dilakukan untuk pembangunan perkantoran menghasilkan sisa tanah untuk pembangunan taman, tapi yang dilakukan oleh subjek kedua ialah dengan menjumlahkan jumlah tanah yang dimiliki oleh pak anton dengan jumlah tanah untuk pembangunan perkantoran dimana ini merupakan kesalahan prosedur yang dilakukan oleh subjek kedua. Kesalahan kedua yang dilakukan oleh subjek kedua ialah hirarki keterampilan, dimana subjek kedua pada penulisan soal siswa tidak menulis dengan benar data yang disajikan. Seharusnya $3 \frac{1}{2}$, tetapi subjek kedua menulis $3 \frac{2}{1}$, namun hasil dari perubahan bentuk pecahan campuran menjadi pecahan biasa adalah benar.

\section{Subjek Ketiga}


Tabel 3. Deskripsi kesalahan dari jawaban subjek ketiga

\begin{tabular}{|l|l|}
\hline \multicolumn{1}{|c|}{ Deskripsi Kesalahan Siswa } & Ada/Tidak Ada \\
\hline Data tidak tepat & - \\
\hline Prosedur tidak tepat & Ada \\
\hline Data yang hilang & Ada \\
\hline Kesimpulan Hilang & Ada \\
\hline Konflik level respon & Ada \\
\hline Manipulasi tidak langsung & Ada \\
\hline Hirarki keterampilan & - \\
\hline Tidak mengerjakan & - \\
\hline
\end{tabular}

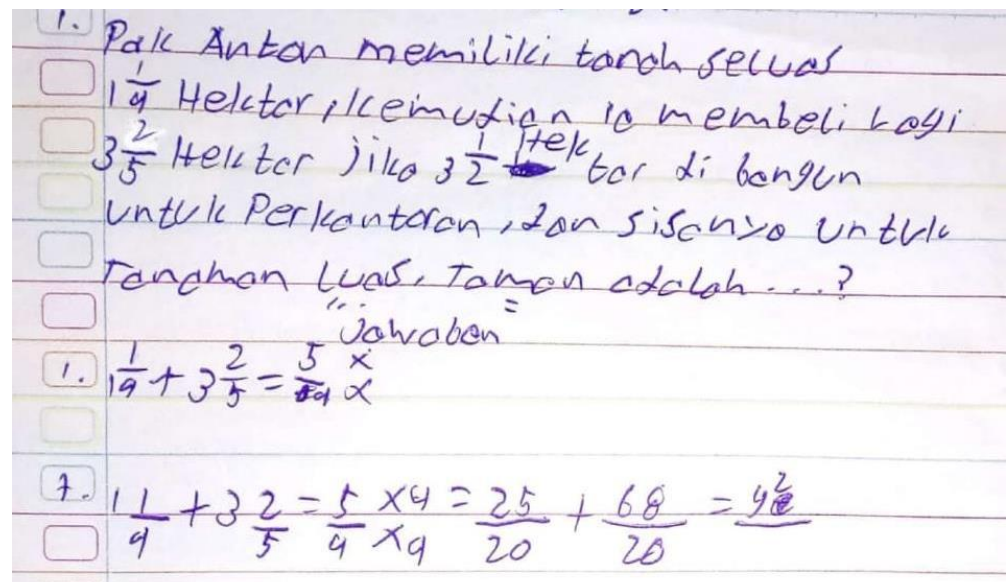

Gambar 3. Jawaban subjek ketiga

Pada subjek ketiga kesalahan yang dilakukan berdasarkan pada tabel 3, tentang deskripsi kesalahan yang dilakukan oleh subjek ketiga ialah prosedur tidak tepat, data yang hilang, kesimpulan yang hilang, dan manipuasi tidak langsung. Pada kesalahan prosedur yang tidak tepat subjek ketiga melakukan kesalahan dengan tidak menuliskan perubahan data dari pecahan campuran menjadi pecahan biasa untuk luas tanah yang dibeli oleh pak anton dan langsung menuliskan hasil dari penyamaan penyebut pada pengerjaan soal tahap pertama, ada dua tahap yang terlewati oleh subjek kedua. Kesalahan berikut ialah data yang hilang, dimana data luas tanah yang dibeli oleh pak anton tidak ada pada pertengahan pengerjaan soal tahap pertama. Kesalahan manipulasi tidak langsung, subjek ketiga langsung menuliskan hasil dari perubahan pecahan campuran dan penyamaan penyebut pada data luas tanah yang dibeli oleh pak anton dengan alasan yang tidak jelas. Dan terakhir ialah kesimpulan yang hilang, dimana suibjek ketiga tidak mengerjakan soal sampai ke tahap akhir.

\section{B. Pembahasan}

Kriteria Watson yang dikaji dalam penelitian ini meliputi:

1. Id (kesalahan dalam menggunakan/ memakai data)

2. Ip (kesalahan dalam prosedur, seperti salah menggunakan rumus, operasi bilangan, tanda operasi)

3. Od (terdapat data yang hilang)

4. Oc (tidak memiliki kesimpulan akhir)

5. Rlc (mengerjakan tidak menggunakan konsep atau menjawab langsung tanpa cara yang logis)

6. Um (melakukan manipullasi tidak logis)

7. Shp (sudah tepat menggunakan konsep tapi kurang terampil dalam memanipulasi rumus)

8. Ao (selain ketujuh kategori, seperti tidak mengerjakan) 
Tabel 4. Kesalahan yang dilakukan subjek

\begin{tabular}{|c|c|c|c|c|c|c|c|c|}
\hline Nomor Subjek & \multicolumn{7}{|c|}{ Kesalahan yang dilakukan Subjek } \\
\cline { 2 - 10 } & Id & Ip & Od & Oc & Rlc & Um & Shp & Ao \\
\hline 1 & - & $\sqrt{ }$ & - & - & - & - & - & - \\
\hline 2 & $\sqrt{ }$ & $\sqrt{ }$ & - & - & $\sqrt{ }$ & - & $\sqrt{ }$ & - \\
\hline 3 & - & $\sqrt{ }$ & $\sqrt{ }$ & $\sqrt{ }$ & $\sqrt{ }$ & $\sqrt{ }$ & - & - \\
\hline
\end{tabular}

Berdasarkan tabel 4 diatas, kesalahan yang dilakukan oleh subjek pertama yang memiliki kemampuan tinggi ialah melakukan prosedur yang tidak tepat. Pada proses pengerjaan soal yang dilakukan oleh subjek pertama memiliki kekeliruan pada saat menuliskan pecahan tapi tidak sempurna. Sebagaimana pada gambar dibawah ini.

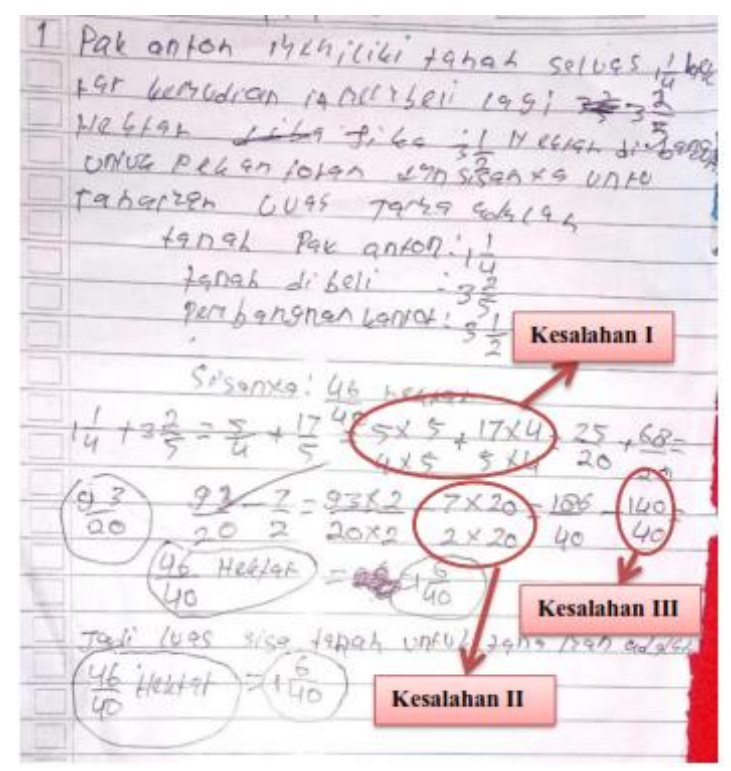

Gambar 4. Kesalahan subjek pertama

Hasil analisis jawaban siswa yang dilakukan tidak selamanya memberikan jawaban yang sebenarnya. Mungkin saja penyebab kesalahan yang peneliti kemukakan dalam analisi kesalahan jawaban siswa tidak sesuai dengan apa yang dipikirkan oleh siswa yang bersangkutan. Oleh sebab itu, peneliti melakukan wawancara terhadap subjek yang dipilih.

Berdasarkan hasil wawancara yang diperoleh dari subjek pertama bahwa kesalahan yang ia lakukan merupakan kelalaian dan bukanlah merupakan kesalahan karena kurang pahamnya subjek dengan permasalahan atau prosedur pengerjaannya. Namun dalam mengerjakan permaslahan matematika tidak perpaku pada hasil akhir dari permasalahan, melaikan penggunaan data dan prosedur yang tepat akan menghasilkan pemahaman konsep yang baik bagi para anak didik.

Untuk subjek kedua, memiliki kesalahan pada penggunaan data yang tidak tepat, prosedur yang tidak tepat, konflik level respon, dan hirarki keterampilan. Sebagimana tertera pada gambar dibawah ini. 


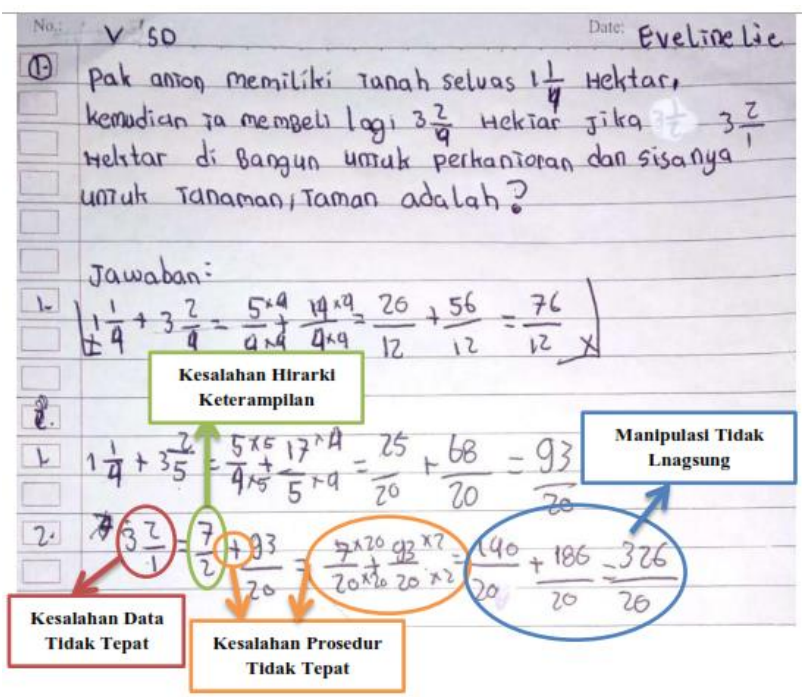

Gambar 5. Kesalahan subjek kedua

Kesalahan pertama yang dilakukan oleh subjek kedua ialah penggunaan data yang tidak tepat pada gambar 4.5 ditunjukan dengan lingkaran warna merah, dimana subjek kedua pada penulisan soal siswa tidak menulis dengan benar data yang disajikan, yang semestinya $3 \frac{1}{2}$, tetapi subjek kedua menulis $3 \frac{2}{1}$ namun hasil dari perubahan bentuk pencahan campuran menjadi pecahan biasa adalah benar. Kesalahan yang kedua ialah prosedur yang tidak tepat pada gambar ditunjukan dengan lingkaran warna kuning, pada kasus prosedur yang tidak tepat kesalahan yang dilakukan oleh subjek ialah pada pengerjaan soal tahap kedua yang semestinya jumlah keseluruhan tanah dari Pak Anton dikurangi dengan luas tanah yang dilakukan untuk pembangunan perkantoran menghasilkan sisa tanah untuk pembangunan taman, tapi yang dilakukan oleh subjek kedua ialah dengan menjumlahkan jumlah tanah yang dimiliki oleh pak anton dengan jumlah tanah untuk pembangunan perkantoran, kesalahan prosedur lainnya ketika menyamakan penyebut $\quad \frac{7}{20}+\frac{93}{20}, \quad$ subjek kedua melakukannya dengan cara $\frac{7 \times 20}{20 \times 20}+\frac{93 \times 2}{20 \times 2}$, yang seharusnya $\frac{7 \times 20}{20 \times 20}+\frac{93 \times 20}{20 \times 20}$.
Kesalahan ketiga yang dilakukan oleh subjek kedua ialah hirarki keterampilan pada gambaar ditunjukan dengan lingkaran berwarna hijau, pada kasus ini subjek kedua menuliskan hasil perubahan pecahan campuran $3 \frac{2}{1}$ menjadi $\frac{7}{2}$ dalam bentuk pecahan biasa $\frac{5}{1}$ atau biasa dituliskan 5 . Kesalahan berikutnya adalah manipulasi tidak langsung pada gambar ditunjukan dengan lingkaran berwarna biru, subjek kedua menuliskan hasil dari penyamaan penyebut $\frac{7 \times 20}{20 \times 20}+\frac{93 \times 2}{20 \times 2}$ adalah $\frac{140}{20}+\frac{186}{20}$ yang seharusnya $\frac{140}{400}+\frac{186}{40}$.

Dari hasil wawancara yang dilakukan bersama subjek kedua bahwa kesalahan yang ia lakukan merupakan kelalaian, tidak cermatnya subjek dalam memperhatikan data, memahami maksud dan tujuan dari permasalahan yang dicari serta tidak cermatnya subjek dalam proses pengerjaannya. Disamping itu waktu pengerjaan soal yang menurut subjek yang terlalu singkat menyebabkan subjek tergesa-gesa dalam memahami maksud dari soal dan tergesa-gesa dalam proses pengerjaannya. Pada kasus waktu yang singkat menurut subjek, faktor kurang cepatnya subjek dalam memahami maksud dari permasalahan menjadi permasalahan utama atau tingkat kemampuan siswa dalam memahami soal tergolong sedang 
karena mampu memahami isi permasalahan dari soal tapi membutuhkan waktu yang cukup lama.

$$
\text { Selanjutnya kesalahan yang }
$$
dilakukan oleh subjek ketiga yaitu prosedur tidak tepat, data hilang, kesimpulan hilang, konflik level respon, dan manipulasi tidak langsung. Sebagimana tertera pada gambar dibawah ini.

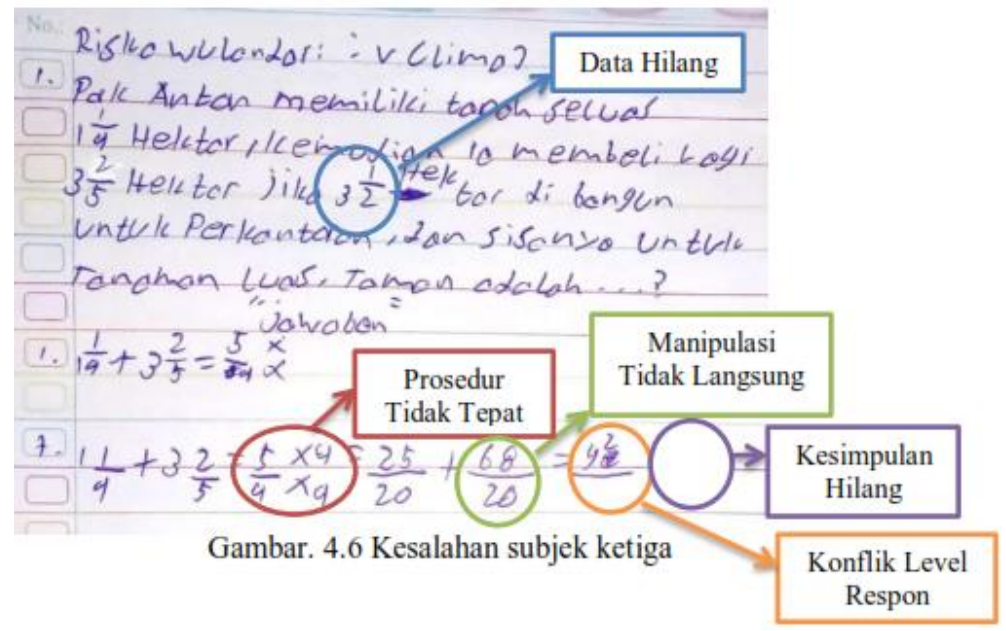

Kesalahan pertama yang dilakukan oleh subjek ketiga adalah prosedur tidak tepat, dimana subjek ketiga hanya menuliskan satu data pecahan campuran yang diubah menjadi pecahan biasa. Yang semestinya subjek ketiga harus mengubah dua data pecahan campuran kebentuk pecahan biasa sebelum melakukan penjumlahan. Kesalahan yang kedua yaitu data hilang, data luas tanah pak anton yang dibangunkan perkantoran $3 \frac{1}{2}$ hektar tidak ada dalam pengerjaannya. Kesalahan ketiga yaitu manipulasi tidak langsung, dimana subjek ketiga langsung menuliskan hasil dari penyamaan penyebut $3 \frac{2}{5}$ menjadi $\frac{68}{20}$ tanpa menuliskan perubahan awal $3 \frac{2}{5}$ menjadi pecahan biasa. Dan kesalahan yang terakhir adalah Kesimpulan Hilang, dimana subjek ketiga tidak mengerjakan soal sampai ketahap akhir untuk mendapatkan kesimpulan yang diinginkan.

Pada wawancara dengan subjek ketiga, peneliti memberhentikan proses wawancara karena menurut peneliti subjek ketiga tidak memahami betul materi ini dan sangat lamban dalam memahami soal yang menyebabkan banyaknya kesalahan dan kekeliruan yang dilakukan oleh subjek ketiga. Sehingga peneliti menarik kesimpulan bahwa subjek ketiga tidak dapat mengerjakan soal yang diberikan.

\section{KESIMPULAN}

Jika dilihat dari keseluruhan kriteria kesalahan pengerjaan soal siswa maka yang terbanyak dilakukan subjek adalah kesalahan tipe Id (data tidak tepat), Ip (Prosedur tidak tepat), Od (Data yang hilang), $O c$ (kesimpulan yang hilang), Rlc (Konflik level respon), Um (Manipulasi tidak langsung), Shp (Hirarki keterampilan). Dan kesalahan yang paling banyak dilakukan oleh subjek 1, 2, dan 3 adalah kesalahan tipe IP (Prosedur Tidak Tepat), dan RLC (Konflik Level Respon). Dimana selama peneliti menganalisis jawaban yang subjek buat, kedua tipe kesalahan ini yang menentukan nilai subjek. Sehingga ini perlu diantisipasi oleh guru yang menandakan kemungkinan mereka belum mengerti materi yang disampaikan.

Untuk kesalahan tipa ip ini memang bermacam-macam, tetapi yang menjadi masalah jika kesalahan siswa adalah salah menentukan cara untuk menyelesaikan 
permasalahan yang diberikan ini menunjukan bahwa siswa belum paham maksud dari soal. Sedangkan tipe rlc ini siswa butuh latihan dan pengutan dalam menyelesaikan permasalahan agar siswa dapat dengan tegas menentukan langkahlangkah mengerjakan soal. Sehinngga jika siswa bertemu dengan soal yang mirip siswa dapat menentukan langkah untuk mengerjakannya. Dari kedelapan tipe kesalahan, kesalahan yang belumm terjadi adalah kesalahan tipe ao atau tidak mengerjakan.

Berdasarkan kesimpulan diatas, maka beberapa hal yang perlu penulis serukan demi meningkatkan kualitas pembelajaran matematika pada umumnya untuk mengatasi kesalahan dalam menyelesaikan soal cerita pada materi operasi pecahan. Beberapa alternatif pemecahan masalah terhadap kesalahankesalahan yang dilakukan untuk menyelesaikan soal cerita yang disajikan pada setiap jenis kesalahan adalah:

a. Guru hendaknya menekankan pentingnya menuliskan prosedur penyelesaian soal secara lengkap;

b. Guru hendaknya memberikan proses tahapan perolehan penyelesaian soal yang ada sehingga siswa tidak hanya sekedar menghafalkan rumus atau cara penyelesaian tersebut;

c. Guru hendaknya memberikan catatan dipapan tulis dibuat sejelas mungkin sehinggga tidak menimbulkan makna ganda;

d. Guru hendaknya memperbanyak latihan soal, dengan sendirinya siswa akan paham cara penyelesaian soal yang akan dihadapnya nanti;

e. Membaca soal berulang-ulang, dan berusaha menterjemahkan maksud soal;

f. Dalam melakukan perhitungan hendaknya dilakukan dengan teliti;

Membiasakan mengecek kembali jawaban dan menyesuaikan dengan konsep yang ada, untuk mengetahui masuk akal atau tidaknya suatu jawaban serta langkah penyelesaiannya.

\section{DAFTAR PUSTAKA}

Asikin, M. 2003. Pengembangan Item Tes dan InterPrestasi Respon Mahasiswa dalam Pembelajara Geometri Analit Pada Taksonomi Solo. Singaraja:Jurnal Pendidikan dan Pengajaran IKIP Negeri, No. 4 TH. XXXVI Oktober

$\begin{array}{rrr}\text { Budiyono, } & 2008 . & \text { Kesalahan } \\ \text { Mengerjakan Soal Cerita } & \text { Dalam Pelajaran Matematika, }\end{array}$ Solo: Jurnal penelitian pendidikan Vol. 11

Sugiyono. 2013. Metode Penelitian Manajemen. Bandung:Alfabeta 